УДК 619:616.995.428:636.7 (477.53)

(C) 2015

Свстаф'єва В. О., доктор ветеринарних наук,

Гаврик К. А., здобувач

Полтавська державна аграрна академія

\title{
ПОШИРЕННЯ АКАРОЗІВ СОБАК В УМОВАХ МІСТА КРЕМЕНЧУКА
}

\section{Рецензент - доктор ветеринарних наук М. В. Скрипка}

\begin{abstract}
Представлені результати визначення видового складу акариформних кліщів, які паразитують на собаках міста Кременчука. Вивчено поширення акарозів собак, а також сезонну та вікову динаміки інвазій. Внаслідок акарологічних досліджень встановлено значне ураження собак демодексами, отодектесами та саркоптесами. Демодекозом і саркоптозом хворіють дорослі собаки, отодектозом - молодняк до 6-місячного віку. Акарози собак у Кременчуці реєструються впродовж року, проте демодекозна інвазія припадає на весняно-осінній, отодектозна - літньо-зимовий, саркоптозна - осінньо-зимовий періоди року.
\end{abstract}

Ключові слова: собаки, саркоптоз, отодектоз, демодекоз, екстенсивність інвазії, поширення, вікова та сезонна динаміки.

Постановка проблеми. Акарози собак поширені на всіх материках, де мешкають м'ясоїдні тварини. Вони мають широкий ареал і проникають слідом за людиною і тваринами у все нові місця існування. Збудники акарозів уражають практично будь-які культурні рослини, будьяких домашніх і промислових тварин, викликаючи такі інвазійні захворювання, як демодекоз, саркоптоз, нотоедроз, отодектоз, хейлетіоз та інші $[1,2,11]$.

Важливу роль у розвитку шкірних захворювань відіграють акарози, викликані саркоптіформними та тромбідіформними кліщами. За даними науковців $[3,12]$, в останні роки відзначена тенденція до збільшення поширення арахнозів м'ясоїдних тварин. Це пов'язано з підвищенням поголів'я собак і котів, збільшенням популяції бродячих тварин (джерел інвазії), утриманням собак і котів на низькому рівні ветеринарного обслуговування.

Тому встановлення видового складу та поширення акарозів собак в умовах невеликих міст залишається актуальною проблемою.

Аналіз основних досліджень і публікацій, у яких започатковано розв'язання проблеми. Питаннями поширення акарозів собак займалися науковці різних країн світу таких, як США, Канада, Індія, Польща, Білорусь, Росія тощо [4-6]. 3'являються літературні повідомлення про поширення акарозів серед дрібних свійських тварин і на території України [9].

3-поміж паразитарних захворювань, які викликають ураження шкіри у собак, діагностують переважно саркоптоз, отодектоз та демодекоз. Збудники цих інвазій можуть викликати зараження і у людей 3 проявом характерних клінічних ознак [13].

На ступінь ураженості собак демодексами, отодектесами та саркоптесами впливає віковий і сезонний фактори, які $є$ основними в епізоотології акарозів. Більшість авторів стверджує, що на акарози хворіють переважно молоді тварини, а максимальний прояв інвазії в собак спостерігається восени, взимку та навесні, що пов'язано 3 підвищенням вологості й зниженням інсоляції $[7,10]$. Інші дослідники стверджують, що акарози в собак реєструються у будь-якому віці та в будь-яку пору року [8].

Метою досліджень було вивчення поширення акарозів собак в умовах міста Кременчука.

У завдання входило: визначити видовий склад збудників акарозів собак, встановити показники екстенсивності інвазії та з'ясувати вікову й сезонну динаміку за акарозів собак.

Матеріал і методи досліджень. Дослідження проводились упродовж 2013-2014 рр. на базі Кременчуцької міської державної лабораторії ветеринарної медицини.

Матеріалом досліджень були собаки, які надходили в клініки ветеринарної медицини м. Кременчука. Всього клінічно обстежено 1143 собаки сорока різних порід і вікових груп, у тому числі й безпородних.

Діагностику акарозів здійснювали комплексно: за даними анамнезу, клінічних ознак та результатами лабораторних досліджень. Водночас враховували пору року, вік та породу собак. Під час клінічного обстеження хворих тварин враховували локалізацію й площу ураження, характер змін шкіряного покриву, наявність свербежу.

Для лабораторних досліджень відбирали глибокі зіскрібки (площею $\left.2 \mathrm{~cm}^{2}(2 \mathrm{x} 1 \mathrm{~cm})\right)$ скальпелем до появи сукровиці на межі ураженої та здо- 


\section{ВЕТЕРИНАРНА МЕДИЦИНА}

рової шкіри, а в разі підозри на отодектоз для дослідження відбирали кірочки 3 внутрішньої поверхні вушних раковин. Відібрані зіскрібки досліджували вітальним методом за А. В. Алфімовою. Остаточний діагноз на акарози (саркоптоз, отодектоз, демодекоз) встановлювали у разі виявлення кліщів у процесі мікроскопічного дослідження зіскрібків з уражених ділянок шкіри за допомогою мікроскопу MICROmed XS 5520 (x 100).

3 метою 3'ясування вікової динаміки акарозів собак виявлених хворих тварин було поділено на 6 вікових груп: до 6-ти міс., 6-12 міс., 1-3 р., 36 р., 6-10 р. та старші 10-ти років. Сезонну динаміку визначали за показниками ураженості собак акариформними кліщами у різні пори року (весна, літо, осінь, зима). Відсоток інвазованих тварин вираховували за показником екстенсивності інвазії (EI).

Результати дослідження. У ході вивчення видового складу збудників акарозів собак в умовах м. Кременчука встановлено, що тварини, уражені акариформними кліщами трьох видів: Demodex canis Leydig, 1859; Otodectes cynotis Hering, 1838; Sarcoptes canis Gerlach, 1857. Водночас ураженість собак акарифорними кліщами у м. Кременчуці в 2013-2014 рр. в середньому становила $41,99 \%$ (табл. 1 ).

Як бачимо 3 таблиці 1, найбільше собаки уражалися збудниками демодекозу та отодектозу (ЕI становила 20,21 та 13,04 \% відповідно). Рідше реєстрували саркоптоз $(\mathrm{EI}=8,75$ \%).

Результатами власних досліджень доведено, що ступінь ураження акариформними кліщами залежав від віку собак та пори року (табл. 2, 3).

Найбільш ураженими збудниками акарозів виявилися собаки віком від одного до шести років, а також старше 10-ти років (43,08-44,25 та $55 \%$ відповідно) (табл. 2).

Демодексами інвазувалися переважно собаки віком 1-3 роки та старше 6-ти років (25,07 та 22,22-25 \% відповідно), отодектесами - до 6-ти місячного віку та віком від 3-х до 6-ти років (17,37 та 14,63 \% відповідно), саркоптесами - 36 років та старше 10-річного віку $(11,15$ та $20 \%$ відповідно).

Отже, у віковому аспекті найбільш вразливі до зараження збудником демодекозу собаки старше однорічного віку, отодектозу - до 6-місячного віку, саркоптозу - старше десятирічного віку.

Сезонна динаміка перебігу акарозів собак наведена у таблиці 3.

\section{1. Поширення акарозів собак у м. Кременчуці}

\begin{tabular}{|c|c|c|c|}
\hline \multirow{2}{*}{ Інвазія } & \multirow{2}{*}{$\begin{array}{c}\text { Кількість обстежених } \\
\text { тварин }\end{array}$} & \multicolumn{2}{|c|}{ Інвазовано } \\
\cline { 4 - 4 } & \multirow{3}{*}{1143} & тварин, голів & ЕІ, \% \\
\hline Демодеко3 & 231 & 20,21 \\
\hline Отодекто3 & & 149 & 13,04 \\
\cline { 1 - 2 } Саркопто3 & 100 & 8,75 \\
\cline { 4 - 4 } & & 480 & 41,99 \\
\hline Усього & &
\end{tabular}

2. Вікова динаміка демодекозу, отодектозу та саркоптозу собак

\begin{tabular}{|c|c|c|c|c|c|c|c|c|c|}
\hline \multirow{3}{*}{$\begin{array}{c}\text { Вік } \\
\text { собак }\end{array}$} & \multirow{3}{*}{$\begin{array}{c}\text { Кількість } \\
\text { обсте- } \\
\text { жених } \\
\text { тварин }\end{array}$} & \multirow{2}{*}{\multicolumn{2}{|c|}{$\begin{array}{c}\text { Інвазовано на } \\
\text { акарози }\end{array}$}} & \multicolumn{6}{|c|}{ Виявлено уражених } \\
\hline & & & & \multicolumn{2}{|c|}{ демодекозом } & \multicolumn{2}{|c|}{ отодектозом } & \multicolumn{2}{|c|}{ саркоптозом } \\
\hline & & голів & $\%$ & голів & $\%$ & голів & $\%$ & голів & $\%$ \\
\hline До 6-ти міс. & 213 & 91 & 42,72 & 39 & 18,31 & 37 & 17,37 & 15 & 7,04 \\
\hline 6-12 міс. & 177 & 61 & 34,46 & 24 & 13,56 & 23 & 12,99 & 14 & 7,91 \\
\hline $1-3 \mathrm{p}$ & 383 & 165 & 43,08 & 96 & 25,07 & 38 & 9,92 & 31 & 8,09 \\
\hline $3-6 \mathrm{p}$ & 287 & 127 & 44,25 & 53 & 18,47 & 42 & 14,63 & 32 & 11,15 \\
\hline $6-10 \mathrm{p}$ & 63 & 25 & 39,68 & 14 & 22,22 & 7 & 11,11 & 4 & 6,35 \\
\hline $\begin{array}{c}\text { Старше 10-ти } \\
\text { років }\end{array}$ & 20 & 11 & 55 & 5 & 25 & 2 & 10 & 4 & 20 \\
\hline Усього & 1143 & 480 & 41,99 & 231 & 20,21 & 149 & 13,04 & 100 & 8,75 \\
\hline
\end{tabular}


ВЕТЕРИНАРНА МЕДИЦИНА

3. Сезонна динаміка демодекозу, отодектозу та саркоптозу собак

\begin{tabular}{|c|c|c|c|c|c|c|c|c|c|}
\hline \multirow{3}{*}{ Пора року } & \multirow{3}{*}{$\begin{array}{c}\text { Кількість } \\
\text { обсте- } \\
\text { жених } \\
\text { тварин }\end{array}$} & \multirow{2}{*}{\multicolumn{2}{|c|}{$\begin{array}{l}\text { Інвазовано } \\
\text { на акарози }\end{array}$}} & \multicolumn{6}{|c|}{ Виявлено уражених } \\
\hline & & & & \multicolumn{2}{|c|}{ демодекозом } & \multicolumn{2}{|c|}{ отодектозом } & \multicolumn{2}{|c|}{ саркоптозом } \\
\hline & & голів & $\%$ & голів & $\%$ & голів & $\%$ & голів & $\%$ \\
\hline Весна & 320 & 134 & 41,88 & 78 & 24,38 & 32 & 10 & 24 & 7,5 \\
\hline Літо & 396 & 171 & 43,18 & 64 & 16,16 & 75 & 18,94 & 32 & 8,08 \\
\hline Осінь & 250 & 109 & 43,6 & 63 & 25,2 & 20 & 8 & 26 & 10,4 \\
\hline Зима & 177 & 66 & 37,29 & 26 & 14,69 & 22 & 12,43 & 18 & 10,17 \\
\hline Всього & 1143 & 480 & 41,99 & 231 & 20,21 & 149 & 13,04 & 100 & 8,75 \\
\hline
\end{tabular}

За демодекозу собак пік ЕІ реєстрували навесні $(24,38 \%)$ та восени $(25,2 \%)$ зі спадом відсотку ураженості тварин взимку (14,69\%) і влітку $(16,16 \%)$. Отодектозна інвазія характеризувалася максимальними показниками ЕI влітку $(18,94 \%)$ та взимку $(12,43 \%)$ із подальшим зниженням ступеню ураженості тварин у весняний $(10 \%)$ та осінній $(8 \%)$ періоди року. Екстенсивність саркоптозної інвазії в собак упродовж року трималася на рівні 7,5-10,4 \%, але максимальний відсоток інвазування спостерігали в осінньозимовий період року (10,17-10,4 \%). Мінімальну EI виявляли у весняно-літній період (7,5$8,08 \%$ ).

Отже, демодекоз, отодектоз та саркоптоз є поширеними акарозами у м. Кременчуці. Перебіг цих інвазій залежить від віку собак та пори року, що необхідно враховувати у проведенні лаборатор-

\section{БІБЛІОГРАФІЯ}

1. Агринский Н. И. Насекомые и клещи, вредящие сельскохозяйственным животным / Н. И. Агринский. - М. : Издательство сельскохозяйственной литературы, журналов и плакатов, 1962. - $288 \mathrm{c}$.

2. Андреева A. B. Эпизоотическая обстановка по демодекозу собак / А. В. Андреева, 3. М. Кидрасова : материалы конференции [«Актуальные проблемы ветеринарной медицины, животноводства, товароведения, обществознания и подготовки кадров на Южном Урале на рубеже веков»]. - Троицк, 2000. - Ч. 1. - С. 3-4.

3. Бэне Ф. Демодекоз собак / Ф. Бэне // Ветеринар. - 1997. - №1. - С. 6-18.

4. Головина О. В. Эпизоотологический мониторинг при экто- и эндопаразитозах плотоядных : дисс. на соиск. уч. степ. к.вет.н. : спец. 03.02.11 / О. В. Головина. - М., 2010. - 173 с. них досліджень тварин та складанні заходів із профілактики демодекозу, отодектозу і саркоптозу.

\section{Висновки:}

1. Встановлено, що найбільш поширеними акарозами собак у м. Кременчуці $є$ демодекоз $(\mathrm{EI}=20,21 \%)$, отодектоз $(13,04 \%)$ та саркоптоз $(8,75 \%)$.

2. Максимально ураженими демодексами виявилися собаки старше однорічного віку (ЕI до $25,07 \%$ ), отодектесами - до 6-місячного віку $(17,37 \%)$, саркоптесами - старше десятирічного віку (20\%).

3. Акарози собак у м. Кременчуці реєструються впродовж року, проте пік демодекозної інвазії припадав на весняний $(24,38 \%)$ та осінній $(25,2 \%)$ періоди, отодектозної - літній $(18,94 \%)$ та зимовий $(12,43 \%)$, саркоптозної - осінній $(10,4 \%)$ та зимовий $(10,17 \%)$ сезони.

5. Дороніна О. Г. Епізоотологія акарозів собак i котів / О.Г. Дороніна, А. М. Титаренко, В. Ф. Галат // Проблеми зооінженерії та ветеринарної медицини : [зб. матеріалів V з'їзду паразитоценологів України]. - Х., 2001. - Вип.7 (31). C. 232-233.

6. Особенности арахноэнтомозов у домашних животных в городских условиях / Г.В.Жемчуева : материалы VII Междунар. конф. [«Проблемы ветеринарной медицины мелких домашних животных»]. - М., 2000. - С. 268-270.

7. Катаева T.C. Эпизоотология и терапия основных арахнозов домашних животных в Краснодарском крае : автореф. дисс. на соиск. уч. степ. д.вет.н. / Т. С. Катаева. - М., 2009. - 42 с.

8. Ларионов С. В. Морфологические особенности клещей рода Demodex животных : автореф. дисс. на соиск. уч. степ. д.вет.н. / С. В. Ларионов. 


\section{ВЕТЕРИНАРНА МЕДИЦИНА}

- M., 1991. - 34 c.

9. Майборода E. A. Арахноэнтомозы домашних животных Украины и Юга России / Е. А. Майборода : [зб. матеріалів наук.-практ. конф. молодих вчених «Наукові досягнення в галузі ветеринарної медицини»]. - Х., 1997. C. 32-33.

10. Титаренко А. М. Демодекоз собак (епізоотологія, патогенез, симптоми, діагностика, лікування) : автореф. дис. на здобуття наук. ступеня к.вет.н. / А. М. Титаренко. - К., 2005. - 19 с.
11. Цвіліховський М. Основні напрями роботи 3 хворобами домашніх тварин / М. Цвіліховський, Л. Олійник // Вет. медицина України. 2003. - №8. - C. 13-15.

12. Codiergues M. C. Canine demodicosis / M. C. Codiergues, M. Franc // Recueil de Medicine Veterinar. - 1995. - Vol.171. - №6-7. - P. 383-389.

13. Eckert J. Zur Bedeutung von Hund und Katze in den Infktketten parasitärer Zoonozen in Europa / J. Eckert // Wien. Tierärztl. Mschr. - 1988. - B. 75. - №12. - S. 457-465. 